\title{
Dialektika antara Aliran Hukum Alam dan Hukum Positif dan Relevansi dengan Hukum Islam
}

\author{
Hajar M. \\ Fakultas Syariah dan Ilmu Hukum UIN Sultan Syarif Kasim Riau \\ Jl. HR. Soebrantas No. 155 KM. 15 Tampan Pekanbaru \\ hajaruin@yahoo.com
}

\begin{abstract}
The main research questions in this study are: First, how is the dialectic between the positive law and the natural law? and second, how is its relevance with the Islamic law? The purpose of this study is to understand the dialectic between the positive law and the natural law and its relevance with the Islamic law. The method used in this study is philosophycal approach. The discussion is presented using descriptive analityc method which is then analyzed using juridical qualitative and juridical normative methods. The result concludes that: First, the natural law is both based on the principle of justice and related with the proper law. The positive law is inspired by the insight on the opposite law. The positive law is separated fron the justice and ethics, while the natural law is ideal and higher in its position as the standard of justice. Since the natural law is based on the conscience, it cannot prevail. Second, Islamic law consisting of revelations as well as positive law and natural law can be combined yet still harmonious in nature.
\end{abstract}

Key words : Dialectic, positive law, natural law, relevance, Islamic law

\begin{abstract}
Abstrak
Pokok permasalahan pada penelitian ini adalah, pertama: bagaimana dialektika antara aliran hukum positif dan hukum alam; kedua, bagaimana relevansi dengan hukum Islam? Adapun tujuan dari penelitian ini adalah untuk mengetahui dialektika antara aliran hukum positif dan hukum alam, dan relevansi hukum Islam. Adapun metode yang digunakan dalam penelitian ini adalah philosophy approach. Bahasannya disajikan secara deskriptif analitis, kemudian dianalisis secara kualitatif yuridis dan yuridis normatif. Hasil penelitian menyimpulkan bahwa; pertama: hukum alam disamping didasarkan pada prinsip keadilan, juga berkaitan dengan hukum yang seharusnya. Aliran hukum positif diilhami oleh pandangan tentang hukum yang bertentangan. Hukum positif dipisahkan dari keadilan dan etika, hukum alam bersifat ideal dan lebih tinggi sebagai standar keadilan. Karena hukum alam didasarkan kepada akal, maka tidak dapat bertahan. Kedua, Hukum Islam, selain berupa wahyu, juga hukum positif dan hukum alam, tidak hanya dapat dikombinasikan, tetapi harmonis.
\end{abstract}

Kata kunci: Dialektika, hukum positif, hukum alam, relevansi, hukum Islam 


\section{Pendahuluan}

Pertentangan antara para pemikir yang menyusun dunia dari konsep-konsep dan gagasan-gagasan a priori, dan mereka yang memandang bahwa materi lebih dulu dari gagasan, selalu ada sepanjang sejarah filsafat. Meski banyak dari anatomi kaum idealis versus materialis, metafisis versus positivis, dan lainnya, dalam berbagai cara, perbedaan antara pendekatan Plato dan Aristoteles terhadap masalah alam semesta, merupakan pertentangan khas antara mazhab-mazhab dalam filsafat. ${ }^{1}$

Positivisme sebagai aliran dalam filsafat hukum muncul pada awal abad ke19. Sistem aliran ini didasari oleh beberapa prinsip. Di antaranya, bahwa hanya apa yang tampil dalam pengalaman dapat disebut benar. Prinsip ini diambil-alih dari filsafat empirisme Locke dan Hume. Apa yang dapat dipastikan sebagai kenyataan dapat disebut benar. Ini berarti bahwa tidak semua pengalaman dapat disebut benar, tetapi hanya pengalaman yang sesuai dengan kenyataan. Hanya dengan ilmu pengetahuan dapat ditentukan apakah sesuatu yang dialami merupakan sungguhsungguh suatu kenyataan. Oleh karena semua kebenaran didapat dari ilmu-ilmu pengetahuan, maka tugas filsafat adalah mengumpulkan dan mengatur hasil penyelidikan ilmu-ilmu pengetahuan.

Maksud dari penganut positivisme klasik adalah mencapai suatu pengertian yang menyeluruh tentang dunia dan kehidupan dengan menggunakan metode ilmu pengetahuan. Oleh sebab itu, metode ilmiah perlu diterapkan pada kehidupan manusia dan hidup bersama manusia. Hal ini yang dilakukan oleh Saint-Simon (1760-1825) dan Auguste Comte (1798-1857) di Perancis, kemudian juga Herbert Spencer di Inggris. Dalam hal ini, aliran filsafat mereka disebut positivisme sosiologis. $^{2}$

Positivisme adalah aliran pemikiran yang bekerja berdasarkan empirisme dalam upaya untuk merespon keterbatasan yang diperlihatkan oleh filsafat spekulatif seperti yang menonjol melalui aliran idealisme Jerman klasik, terutama Immanuel Kant. Sebagai aliran pemikiran, positivisme pada mulanya dikembangkan sebagai sosiologi oleh Comte. Comte terkenal dengan teorinya yang mengatakan bahwa kemajuan masyarakat berlangsung menurut "hukum tiga stadium”, yaitu stadium teologis, stadium filsafat, dan stadium positif.

${ }^{1}$ W. Friedmann, Teori dan Filsafat Hukum: Telaah Kritis Atas Teori-teori Hukum, Raja Grafindo Persada, Jakarta, 1990, hlm. 143.

${ }^{2}$ Theo Huijbers, Filsafat Hukum Dalam Lintasan Sejarah, Kanisius, Yogyakarta, 1982, hlm. 122-123. 
Positivisme dalam pengertian modern adalah suatu sistem filsafat yang mengakui hanya fakta-fakta positif dan fenomena-fenomena yang dapat diobservasi. Dengan hubungan obyektif fakta-fakta ini dan hukum-hukum yang menentukannya, meninggalkan semua penyelidikan menjadi sebab-sebab atau asal-usul tertinggi. ${ }^{3}$ Dengan kata lain, positivisme merupakan sebuah sikap ilmiah, menolak spekulasispekulasi a priori, dan berusaha membangun dirinya pada data pengalaman.

Aliran hukum positivisme ini mendapat reaksi, antara lain dari Edmund Husserl (1859-1939). Husserl tidak sependapat dengan perkembangan aliran hukum positivisme, dan karenanya Husserl menciptakan metode baru, yaitu fenomenologi, sebuah metode yang berusaha memecahkan monopoli metode ini bagi semua pengetahuan. Reaksi lain juga muncul dari pihak yang menghidupkan kembali aliran hukum alam. Para tokoh filsafat hukum alam bermaksud untuk membela keadilan sebagai unsur hakiki segala hukum. Unsur ini dilalaikan dalam aliran hukum positif yang tidak mengakui suatu norma etis bagi berlakunya hukum. Menurut mereka, suatu norma etis dibutuhkan untuk menjadi dasar suatu hukum yang sah. Norma etis ini terletak pada hukum alam. ${ }^{4}$

Hukum alam merupakan segala yang ada sesuai dengan aturan semesta alam. Menurut para Sofis Yunani (abad ke-5 SM), Thomas Hobbes, dan lainnya bahwa hukum alam menguasai kehidupan manusia, sama seperti makhluk hidup lainnya yang mengikuti kecenderungan-kecenderungan jasmani. Hukum ini juga membuktikan bahwa terdapat tuntutan fundamental dalam hidup manusia yang nyata dalam wujudnya sebagai makhluk yang berakal budi. Manusia tidak boleh mengikuti nalurinya yang irrasional, melainkan pertimbangan akal budi dan rasa moral. ${ }^{5}$

Pada gilirannya hukum alam mendapat kritikan. David Hume (1711-1776) mengatakan bahwa akal hanya menjadi nafsu dan tidak akan pernah dapat berpretensi selain untuk mengabdi kepada nafsu. Pernyataan Hume ini tidak sekedar merusak fondasi hukum alam, tetapi juga menyatakan secara tidak langsung bahwa secara esensial akal merupakan budak nafsu manusia yang dengan sendirinya mengilhami perbuatan-perbuatan manusia. Akal tidak mengajarkan cara untuk berbuat, tetapi didikte oleh nafsu. Penghapusan secara bertahap hukum alam ini

\footnotetext{
${ }^{3}$ Muhammad Muslehuddin, Philosophy of Islamic Law and the Orientalist: A Comparative Study of Islamic Legal System, Cetakan ke-2, Alihbahasa: Yudian Wahyudi Asmin, Tiara Wacana, Yogyakarta, 1997, hlm. 27.

${ }^{4}$ Theo Huijbers, Op Cit, hlm. 245.

${ }^{5}$ Abdul Ghofur Anshori, Filsafat Hukum, Gajah Mada University Press, Yogyakarta, 2006, hlm. 87-88.
} 
memuncak dalam karya Hume Treatice on Human Nature, yang diterbitkan tahun 1739-1740.

Filsafat hukum alam yang dihidupkan kembali berbeda dengan filsafat hukum alam yang lama. Sebabnya, bahwa aliran hukum alam yang baru ini harus memberikan jawaban pada kritikan mazhab hukum historis dan positvisime yuridis. Salah satu aliran yang memunculkan kembali aliran hukum alam adalah neothomisme. Aliran ini terinspirasi pada filsafat Thomas Aquinas yang hidup dalam abad pertengahan. Filsafat ini oleh para ahli disesuaikan dengan perundangundangan baru masa kini.

Menurut para filsuf hukum, pada aliran neothomisme terdapat suatu hukum alam yang berada di atas hukum positif. Hukum alam ini berakar dari dalam suatu aturan alam metafisis, sebagaimana direncanakan Tuhan. Hukum alam ditanggapi sebagai suatu hukum yang memiliki kekuatan hukum yang real dan yang dapat dikenal oleh akal budi manusia. Bila hukum alam dipandang seperti demikian, harus diakui bahwa hukum alam melebihi hukum positif, dan karenanya juga dapat menghilangkan kekuatannya. Seperti dikatakan oleh Radbruch, bahwa hukum alam memecahkan hukum positif (Naturrecht bricht Positives Recht). ${ }^{6}$

Kedua aliran hukum di atas, diduga mempunyai relevansi dengan hukum Islam, karena untuk menetapkan hukum dalam Islam diperlukan pertimbanganpertimbangan yang dikaji oleh aliran hukum positif dan hukum alam.

\section{Rumusan Masalah}

Berdasarkan fenomena yang dikemukakan di atas, permasalahan pada penelitian ini: pertama, bagaimana dialektika antara aliran hukum positif dan aliran hukum alam; Kedua, bagaimana relevansi hukum Islam terhadap aliran hukum positif dan aliran hukum alam?

\section{Tujuan Penelitian}

Kajian ini bertujuan untuk mengetahui: pertama, dialektika antara aliran hukum positif dan aliran hukum alam; Kedua, mengetahui relevansi hukum Islam terhadap aliran hukum positif dan aliran hukum alam.

${ }^{6}$ Theo Huijbers, Op Cit., hlm. 245. 


\section{Metode Penelitian}

Penelitian ini menggunakan pendekatan filosofis (philosophy approach). Datanya berasal dari data sekunder, dengan menggunakan bahan hukum primer (primary sources or authorities) dan sekunder (secondary sources or authorities). Data disajikan secara deskriptif analitis, kemudian dianalisis secara yuridis normatif.

\section{Hasil Penelitian dan Pembahasan}

\section{Dialektika antara Aliran Hukum Alam dan Hukum Positif}

Menelusuri sejarah hukum alam berarti mengikuti sejarah manusia yang berjuang menemukan suatu keadilan mutlak dengan berbagai persoalan yang dihadapi. Sejak ribuan tahun yang lalu, ide tentang hukum alam selalu saja muncul sebagai suatu manifestasi usaha manusia merindukan adanya hukum yang lebih tinggi dari hukum positif. Pada saat tertentu, ide tentang hukum alam muncul dengan segala kejayaannya, dan di saat lainnya diabaikan. Namun, bagaimanapun hukum alam tidak pernah mati.

Dalam perjalanan sejarahnya, hukum alam telah menjalankan dan melayani berbagai fungsi. Menurut Friedman, di antara fungsinya adalah: a) sebagai instrumen utama pada saat hukum perdata Romawi Kuno ditransformasikan menjadi suatu sistem internasional; b) menjadi senjata yang dipakai oleh pihak gereja dan kerajaan dalam pergaulan antara mereka; c) hukum internasional ditegakkan berdasarkan keabsahan dan atas nama hukum alam; d) menjadi tumpuan pada saat orang melancarkan perjuangan bagi kebebasan individu berhadapan dengan absolutisme; e) prinsip-prinsip hukum alam telah dijadikan senjata oleh para hakim Amerika ketika mereka memberikan penafsiran terhadap konstitusi mereka, dengan menolak campur tangan negara melalui perundang-undangan yang ditujukan untuk membatasi kemerdekaan ekonomi. ${ }^{7}$

Hukum alam sesungguhnya merupakan suatu konsep yang mencakup banyak teori di dalamnya. Berbagai anggapan dan pendapat yang dikategorikan kepada hukum alam bermunculan dari masa ke masa. Istilah hukum alam ini ditangkap dalam berbagai arti oleh berbagai kalangan pada masa yang berbeda. Dias,

${ }^{7}$ Satjipto Rahardjo, Ilmu Hukum, Cetakan V , Citra Aditya Bakti, Bandung, 2000, hlm. 260-261. 
sebagaimana dikutip oleh Rahardjo menyebutkan bahwa: a) hukum alam merupakan ideal-ideal yang menuntun perkembangan hukum dan pelaksanaannya; b) hukum alam sebagai suatu dasar dalam hukum yang bersifat moral, yang menjaga agar jangan terjadi suatu pemisahan secara total antara "yang ada sekarang" dan "yang seharusnya"; c) hukum alam sebagai metode untuk menemukan hukum yang sempurna; d) hukum alam adalah isi dari hukum yang sempurna, yang dapat dideduksikan melalui akal; e) hukum alam adalah suatu kondisi yang harus ada bagi kehadiran hukum. ${ }^{8}$

Sebagai tercermin pada butir-butir di atas, hukum alam dapat berupa metode, dan dapat pula sebagai substansi. Hukum alam sebagai substansi memuat normanorma. Dalam anggapan ini, orang dapat menciptakan sejumlah besar peraturanperaturan yang dialirkan dari beberapa asas yang absolut, yang lebih dikenal dengan Hak Asasi Manusia. Hukum alam substansi ini memperoleh kritik yang tajam dan mengalami kemunduran sejak abad ke-19, dan digantikan oleh aliran hukum positivisme.

Selama kondisi tetap stabil, aliran hukum positivisme dapat berkembang dengan baik. Akan tetapi, segera aliran hukum positivis gagal dengan terjadi kegoncangan, seperti halnya pada separuh abad ke-19. Kegagalan tersebut dikarenakan ketidakmampuan memberikan tuntunan di tengah terjadinya gugatan terhadap kepercayaan-kepercayaan sosial dan moral pada waktu itu. Aliran hukum positif juga gagal karena tidak mampu memberikan bantuan guna menghindari penggunaan yang salah dari kekuasaan dan kemerdekaan yang terjadi. Dengan mundurnya positivisme, maka hukum alam mendapat tempat untuk lebih berkembang, yang kemudian dikenal dengan sebutan kebangkitan doktrin hukum alam.

Sebagaimana dikemukakan bahwa selama kondisi stabil, positivisme hukum dapat berkembang dengan baik dan dapat menemukan identitasnya. Positivisme hukum sebagai sebuah pendirian lugas yang menyatakan bahwa tidak benar bila hukum-hukum adalah reproduksi atau pemenuhan ketentuan moral, meskipun dalam faktanya hal itu sering terjadi. Namun, karena mereka yang berpegang pada pendirian ini berbeda pendapat tentang hakikat moralitas.

Dalam teori klasik hukum alam disebutkan bahwa terdapat prinsip-prinsip perilaku yang menunggu untuk ditemukan oleh akal, yang harus diikuti oleh hukum

\footnotetext{
${ }^{8}$ Ibid., hlm. 261.
} 
ciptaan manusia jika dikehendaki sebagai yang valid. Hal ini terjadi karena klaim adanya prinsip-prinsip faktual mengenai perilaku yang benar yang dapat ditemukan secara rasional. Biasanya tidak dikemukakan sebagai satu doktrin tersendiri melainkan sejak awal disajikan, dan dipertahankan dalam waktu yang lama sebagai bagian dari sebuah konsep umum tentang alam. Dalam banyak hal, pandangan ini merupakan antitesis atas konsep umum alam yang membentuk kerangka pemikiran sekuler modern. Dari sini terlihat, bagi para pengkritiknya, aliran hukum alam terlihat muncul dari kekacauan lama. Sementara bagi pendukungnya, para pengkritik terlihat hanya berkutat pada hal-hal yang remeh yang mencuat ke permukaan dan mengabaikan kebenaran yang lebih mendalam. ${ }^{9}$

Banyak pengkritik modern berfikir, klaim bahwa hukum-hukum perilaku yang benar dapat ditemukan oleh akal, sesungguhnya bertumpu pada ambiguitas istilah hukum, dan ketika ambiguitas muncul, maka hukum alam akan terhempas mati. Dengan cara ini pula John Stuart Mill menilai Montesquieu secara naif bertanya mengapa benda-benda tidak bernyawa mematuhi hukum alam mereka, sementara manusia tidak melakukan hal yang sama. Menurut Mill, pertanyaan seperti itu mengacaukan antara hukum-hukum yang merumuskan keteraturan alam dan hukumhukum yang menuntut manusia untuk berperilaku dengan cara tertentu. Atas dasar pandangan ini, keyakinan pada hukum alam dapat dilihat hanya sebagai sesat fikir yang amat terang, ketidakmampuan menangkap perbedaan besar antara berbagai makna yang terkandung dalam istilah-istilah yang melekat pada kata hukum. ${ }^{10}$

Doktrin hukum alam adalah bagian dari sebuah konsep kuno mengenai alam, di mana dunia dapat diamati tidak sekedar sebuah panggung keteraturan, dan pengetahuan tentang alam bukan sekedar pengetahuan mengenai suatu keteraturan. Atas dasar ini, setiap jenis wujud yang ada, bukan hanya sedang mempertahankan wujudnya melainkan bergerak menuju suatu keadaan optimum sebagai tujuan akhir.

Dewasa ini hukum alam yang rinci seperti masa klasik dan pertengahan tidak lagi dianggap abadi, karena kedinamisan kehidupan manusia. Namun, prinsip itu tetap ada dengan lebih umum, seperti keadilan, kejujuran, kesopanan, dan sebagainya. Prinsip itu memiliki kestabilan, tetapi juga sebagai suatu kelonggaran untuk berubah sesuai perkembangan zaman. $287-288$.

${ }^{9}$ H.L.A. Hart, The Consept of Law, Cetakan ke-2, Alih bahasa M. Khozim, Nusa Media, Bandung, 2010, hlm. ${ }^{10}$ Ibid., hlm. 289-290. 
Banyak para ahli tidak bersedia menerima adanya dua macam hukum (hukum positif dan hukum alam), yang satu telah menjadi undang-undang, dan yang lain difikirkan sebagai hukum dasar yang lebih kuat dari undang-undang. Oleh karena itu, para ahli senantiasa melembagakan atau memformulasi prinsip-prinsip hukum dengan memasukkannya dalam undang-undang dengan mengadopsinya dalam kerangka yang rasional. Dengan ini pula sebenarnya banyak pemikir menolak positivisme hukum, tetapi sekaligus juga mengakui bahwa hukum yang benar adalah hukum positif.

Para positivis memandang bahwa prinsip-prinsip hukum yang terdapat dalam hukum alam sebagai prinsip regulatif belaka, yaitu sebagai pedoman bagi terbentuknya hukum, dan bukan sebagai prinsip konstitutif dari hukum. Artinya, bahwa prinsip-prinsip tersebut memang harus diindahkan pada saat undang-undang dibentuk. Namun, jika undang-undang yang ada bertentangan dengan prinsipprinsip hukum alam, maka undang-undang tersebut tetap sah berlaku. Dengan kata lain, menurut para positivisme, hukum cenderung menganut prinsip kepastian hukum, dibandingkan dengan para ahli hukum alam yang lebih memperhatikan prinsip keadilan dan kemanfaatan hukum bagi masyarakat. ${ }^{11}$

Akal, betapa pun diagungkan, hanyalah suatu tebakan yang hampir tidak dapat menggantikan kebenaran. Menurut David Hume (1711-1776) bahwa akal adalah menjadi budak nafsu dan tidak akan pernah dapat berpretensi apapun selain mengabdi dan mentaati nafsu-nafsu. ${ }^{12}$

Pernyataan Hume di atas, tidak hanya merusak fondasi-fondasi hukum alam, tetapi juga menyatakan secara tidak langsung bahwa secara esensial akal merupakan budak nafsu manusia yang dengan sendirinya mengilhami perbuatan-perbuatan manusia. Akal sendiri tidak mengajarkan cara untuk berbuat, tetapi didikte oleh nafsu. Kritikan terhadap hukum alam ini memuncak dalam karya Hume "Treatice on Human Nature".

Immanuel Kant dalam karyanya "Critique of Pure Reason", membuktikan keterbatasan akal. Perbedaan dalam konsep-konsep alam dan akal telah mengakibatkan konflik dalam teori-teori hukum alam. Akal dapat berubah dan memberikan blok-blok kepada hukum alam. Sementara, Salmond mengakui keberagaman kualitas dan aspek hukum alam, bahwa hukum alam telah menerima

\footnotetext{
${ }^{11}$ Abdul Ghafur Anshari, Op.Cit., hlm. 91.

${ }^{12}$ Muhammad Muslehuddin, Op. Cit, hlm. 22.
} 
sejumlah nama lain yang mengekspresikan perbedaan kualitas dan aspeknya. Hukum alam disebut hukum Tuhan (jus divinum) yang dibebankan kepada manusia. Aspek ketuhanan ini diterima dalam pantheisme kaum Stoa, dan menjadi konsep utama segera setelah hukum alam memperoleh tempat di dalam sistem filsafat Kristen.

Hukum alam merupakan hukum akal, karena dibangun oleh akal untuk mengatur alam, di samping dialamatkan dan diterima oleh sifat rasional manusia. Hukum alam disebut juga hukum external (lex aeterna) karena telah ada sejak awal adanya dunia, tidak diciptakan dan abadi. Akhirnya, dinamakan hukum moral karena mengekspresikan prinsip-prinsip moralitas. ${ }^{13}$

Hukum alam sebenarnya tidak dapat universal untuk segala waktu dan keadaan, karena akal manusia akan berbeda di antara sesamanya. Ihering telah menolak hukum alam untuk semua bangsa dan waktu karena tidak lebih baik dari pada pemikiran bahwa penyembuhan medis harus sama untuk semua orang. Masyarakat berbeda satu sama lain, baik dalam bentuk, karakter dan sosialnya. Oleh karenanya, hukum bagaimana pun juga merupakan produk lokal, tidak dapat diterapkan kepada mereka secara merata. Masa depan dan kenyataan-kenyataan sosial dalam masyarakat modern menentukan konsep-konsep hukum sehingga hukum tidak dapat berubah.

Bertrand Russel mengatakan bahwa tawanan perang merupakan budak menurut hukum alam. Selain itu, bahwa karena sifat alami, setiap orang harus mempertahankan diri atau hartanya dari serangan pihak lain, meskipun harus dengan membunuh. Russel tidak membuat kualifikasi, sehingga jika seseorang ditangkap dalam suatu pencurian yang relatif kecil, menurut hukum alam, boleh untuk ditembak.

Di sisi lain, hukum alam merupakan sumber terpenting dari material hukum. Hukum alam sebenarnya terdiri dari prinsip-prinsip material hukum, yang tidak bergantung pada kemauan manusia, tetapi berasal dari alam sendiri, dan merupakan dasar hukum positif. Prinsip-prinsip ini harus diterapkan kepada kehidupan sosial melalui pembentukan teknis hukum dan pembentukan yuridis hukum.

Cicero mengatakan bahwa tidak ada satu hal yang lebih penting untuk dipahami selain bahwa manusia dilahirkan bagi keadilan dan bahwa hukum dan keadilan tidak ditentukan oleh pendapat manusia, tetapi ditentukan oleh hukum alam. ${ }^{14}$

\footnotetext{
${ }^{13}$ Ibid., hlm. 23.

${ }^{14}$ Lili Rasyidi, B. Arief Sidharta, (Penyunting), Filsafat Hukum Mað̧ab dan Refleksinya, Cet. Kedua, Remaja Rosdakarya, Bandung, 1994, hlm. 26-27.
} 
Kekuatan manusia pada hakikatnya tidak terletak pada kemampuan fisiknya atau kemampuan jiwanya semata, tetapi terletak dalam kemampuan untuk bekerjasama di antara sesamanya. Dengan adanya kerjasama tersebut, perbedaan-perbedaan pendapat yang muncul akan dapat disamakan. Adanya persamaan pendapat ini sudah barang tentu membuktikan bahwa seluruh umat bersatu.

Alam telah menuntun dan membimbing manusia untuk berlaku adil, dan mendorong untuk menggunakan fikirannya agar tidak mengabaikan hal-hal yang sensitif tentang manusia, sehingga keadilan akan berkembang di antara sesama manusia. Alam juga memberikan akal budi yang tepat untuk membolehkan apa yang baik dan mencegah sesuatu yang jahat. Oleh sebab itu, sangat tepat bahwa hukum yang sebenarnya adalah akal budi yang baik, yang merupakan kaedah sejati dari semua perintah dan larangan. Siapapun yang mengabaikan hukum alam, dengan sendirinya tidak akan terwujud keadilan.

Selanjutnya Messner menilai bahwa hukum positif sebagai hukum yang secara langsung berdasar pada hukum alam. Atau dapat juga sebagai hukum yang secara tidak langsung berdasar pada hukum alam, yaitu sejauh hukum itu dapat berlaku dari kekuasaan negara yang disahkan oleh hukum alam. Jadi, hukum positif yang secara langsung berdasar pada hukum alam mewajibkan dalam batin. Menurut Messner, termasuk juga hukum positif yang secara tidak langsung berdasar pada hukum alam mewajibkan dalam batin juga. Dalam hal ini, ia berbeda dengan Aquinas yang beranggapan bahwa hukum yang terakhir ini merupakan ciptaan manusia belaka. ${ }^{15}$

Bila terjadi pertentangan antara hukum positif dan hukum alam, menurut Messner, hukum positif kehilangan berlakunya. Hal ini berarti bahwa hukum semacam itu tidak mempunyai kekuatan hukum lagi, dan akibatnya sanksi batin juga lenyap.

Hubungan antara hukum alam dan hukum positif, pada umumnya adalah bahwa hukum alam membantu hukum positif dengan menentukan apa yang patut. Lagi pula hukum alam memainkan peranan dalam menggabungkan hukum positif dengan prinsip-prinsip kepentingan umum.

Tokoh lain yang mempertahankan hukum alam dan menolak hukum positif adalah Emil Brunner (1889-1966). Brunner mempunyai keyakinan yang kuat bahwa tidak benar negara berkuasa secara mutlak atas segala tingkah laku warganya. Oleh

${ }^{15}$ Theo Huijbers, Op. Cit, hlm. 255-256. 
karena itu, ia menolak sistem filsafat yang berhubungan dengannya, khususnya positivisme hukum. Tidak mungkin hukum positif merupakan norma tertinggi bagi aturan hidup bersama. Perlu adanya suatu norma kritis, yang merupakan dasar hukum positif. Norma dasar dimaksud adalah hukum alam. ${ }^{16}$

Sebenarnya Brunner tidak mempertentangkan antara hukum alam dengan hukum positif. Menurutnya, hukum alam harus dianggap sebagai suatu ide normatif-kritis, yang minta untuk diwujudkan dalam hukum positif negara. Hukum alam dianggap sebagai hukum yang sah, tetapi hanya sebagai prinsip hukum yang mendapat kekuatan yuridisnya dalam proses pembentukan hukum positif.

Dalam aspek tertentu, positivisme hukum mendapat kritikan. Penggolongan yang dibuat oleh Austin, yang mengkategorikan semua hukum sebagai perintah telah dikritik dari berbagai sisi. Tokoh seperti Bryce, Dicey, dan Gray menganggap bahwa hak-hak privat, undang-undang administratif, dan hukum-hukum deklaratori tidak dapat dikelompokkan sebagai perintah. Selain itu, teori Austin tidak menawarkan solusi dalam menghadapi interpretasi-interpretasi yang bertentangan dengan suatu keadaan atau preseden. Demikian pula pemisahan antara hukum dan keadilan mendapat kecaman dari berbagai tokoh filsafat hukum.

Hal yang sama juga digagas oleh Hans Kelsen, yang membatasi diri pada hukum tanpa memperhatikan unsur keadilan. ${ }^{17}$ Akan tetapi menurut Stammer, kemurnian mutlak bagi teori hukum apapun adalah mustahil. Kelsen harus mengakui manakala teori ini memasuki pertanyaan tentang norma-norma fundamental yang bertentangan. Norma fundamental yang valid, maka teori hukum murninya tidak dapat menghindari, maka tanpa norma fundamental tersebut, maka keseluruhan bangunan hukum itu akan runtuh. ${ }^{18}$ Dari sisi lain, Lauterpacht, seorang pengikut Kelsen, mempertanyakan apakah teori hierarki norma-norma hukum tidak menyatakan secara tidak langsung sebuah pengakuan akan prinsip-prinsip hukum alam, meski Kelsen menyerang keras ideologi aliran hukum alam. ${ }^{19}$

Para penganut hukum alam abad ke-20 telah merasa puas dengan merumuskan beberapa prinsip tertinggi, sedangkan prinsip-prinsip sekunder dapat disimpulkan dari prinsip-prinsip yang utama tersebut, sesudah berkonfrontasi dengan kebutuhan

\footnotetext{
${ }^{16}$ Idem, hlm. 257.

${ }^{17}$ Hans Kelsen, Pure Theory of law, Cetakan ke-6, Alih bahasa Raisul Muttaqin, Nusa Media, Bandung, 2008,

${ }^{18}$ W. Friedmann, Op.Cit., hlm. 285.

${ }^{19}$ Muhammad Muslehuddin, Op. Cit., hlm. 31.
} hlm. 1-2. 
situasi dan masa. Mereka juga menanggapi hukum alam sebagai suatu hukum yang memiliki kekuatan riil, dan dapat dikenal oleh akal budi manusia. Oleh sebab itu, sebenarnya hukum alam melebihi hukum positif, dan karenanya dapat menghilangkan kekuatannya. Hal ini seperti dikatakan oleh Gustav Radbruch (18781949) bahwa hukum alam memecahkan hukum positif.

\section{Relevansi Hukum Islam dengan Aliran Hukum Alam dan Hukum Positif}

Filsafat hukum mengambil pandangan hukum yang bersifat teleologis, yang menyatakan bahwa adanya hukum adalah untuk memenuhi maksud tertentu. Tidak dapat disangkal bahwa setiap sistem hukum diorientasikan untuk mencapai tujuan tertentu yang menuntut pelaksanaan. Hukum Islam adalah sistem ketuhanan yang dinobatkan untuk menuntun umat manusia menuju kedamaian di dunia dan di akhirat. Urusan dunia ini oleh penentu hukum dipandang dari kerangka kepentingan dunia lain, yang lebih baik dan abadi. Hal ini membuktikan perbedaan antara hukum Islam dari hukum yang dibuat manusia yang hanya membicarakan kepentingan dunia belaka.

Tuhan adalah Maha Pengasih dan Maha Penyayang. Sifat ini benar-benar terefleksikan dalam setiap hukum-hukum-Nya. Jadi, rahmat merupakan inti syari'ah dengan konsekuensi bahwa kekuasaan yang berdasarkan pada kekuatan akal semata dicela oleh Tuhan. Mengatur dengan kekuatan akal bukan tujuan syari'ah, sedangkan keadilan merupakan tujuan utama.

Keadilan menurut hukum Islam adalah perintah yang lebih tinggi, karena tidak hanya memberikan kepada setiap orang akan haknya, tetapi juga sebagai rahmat dan kesembuhan qalbu. Berlaku adil dianggap sebagai langkah taqwa setelah beriman kepada Allah. ${ }^{20}$ Oleh sebab itu, hukum Islam merupakan pernyataan Tuhan, dan usaha untuk menegakkan perdamaian di muka bumi dengan mengatur masyarakat dan memberikan keadilan kepada setiap orang. Jadi, perintah dan keadilan merupakan tujuan mendasar bagi hukum Islam (Syari'ah).

Bila diperhatikan positivisme hukum, bahwa perintah merupakan tujuan utamanya. Positivisme hukum tidak menilai lebih rinci, apakah suatu perintah tersebut bersifat adil atau tidak. Di sisi lain, hukum alam, seperti diuraikan oleh Friedmann, merupakan sejarah manusia mencari keadilan mutlak, di mana kegagalannya merupakan bukti bagi definisi-definisi yang bertentangan, dan

\footnotetext{
${ }^{20}$ Al-Quran, Surat Al-Maidah (5), ayat 8.
} 
pandangan-pandangan yang berbeda, dalam hal ini, menyebabkan keadilan tidak dapat dicapai. ${ }^{21}$

Teori dan konsep keadilan sebenarnya sudah dibicarakan sejak Plato hingga ke pemikir sekarang. Kelsen berusaha mereduksi berbagai doktrin keadilan menjadi dua bentuk dasar, yaitu rasionalistis dan metafisis. Tipe rasional sebagai tipe yang berusaha menjawab pertanyaan tentang keadilan dengan cara mendefinisikannya dalam suatu pola ilmiah atau quasi ilmiah. Dalam memecahkan persoalan keadilan, tipe rasional berdasarkan pada akal. Pola ini diwakili oleh Aristoteles. Sedangkan tipe metafisik merupakan realisasi sesuatu yang diarahkan ke dunia lain di balik pengalaman manusia. Pola ini diwakili oleh Plato. Dalam pandangan Dewey, bahwa keadilan tidak dapat didefinisikan, karena merupakan idealisme yang tidak rasional. ${ }^{22}$

Menurut Friedmann, semua usaha dalam rangka untuk menemukan standar keadilan yang mutlak adalah gagal, kecuali dengan dasar-dasar agama. Agama merupakan unsur wahyu dan keimanan tertinggi. Prinsip-prinsip yang ditentukan oleh Tuhan harus dipercayai sebagai bagian dari keyakinan agama seseorang. Di sisi lain, para filsuf yang menjadikan keadilan sebagai masalah intuisi hanya berkhayal. Kepercayaan tertinggi mereka tidak terletak pada prinsip-prinsip keadilan yang abadi, tetapi pada kebijaksanaan, kebaikan atau kekuasaan manusia semata. ${ }^{23}$

Keadilan mutlak hanya ada pada hukum Islam yang didasarkan kepada wahyu, dan memuat prinsip-prinsip keadilan abadi. Seseorang yang hidup menurut hukum Islam, harus berbuat adil, tidak hanya kepada diri sendiri, tetapi juga kepada orang lain dan alam sekitarnya. Allah berfirman dalam surat Asy-Syura (42) ayat 17:

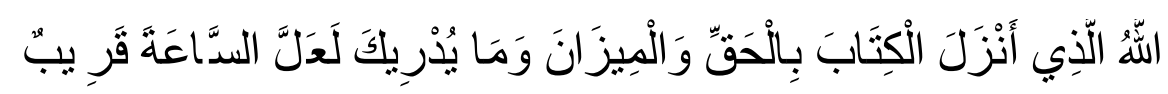

Artinya: Allah-lah yang menurunkan kitab dengan (membawa) kebenaran dan (menurunkan) neraca (keadilan). Dan tahukah kamu, boleh jadi hari kiamat itu (sudah) dekat?

Memang wahyu merupakan neraca untuk menimbang semua persoalan moral, semua masalah tingkah laku yang baik dan yang buruk. Di satu pihak, akal dengan

\footnotetext{
${ }^{21}$ W. Friedmann, Op Cit, hlm. 345.

${ }_{22}$ Abdul Ghafur Anshari, Filsafat Hukum Kewarisan Islam: Konsep Kewarisan Bilateral Hazairin, Cetakan ke-2, UII Press, Yogyakarta, 2010, hlm. 139.

${ }^{23}$ W. Friedmann, Op.Cit., hlm. 347.
} 
berbagai variasinya memberikan berbagai definisi dan bentuk yang bertentangan dengan keadilan, dan karenanya gagal mencapai keadilan itu sendiri. Sedangkan wahyu dengan standar keadilannya yang mutlak, tidak hanya sekedar mencapai keadilan mutlak tersebut, tetapi juga merupakan sumber yang abadi bagi keadilan.

Hukum Islam menyatukan hukum sebagai "adanya" dengan hukum sebagai "seharusnya". Yang "ada" berarti stabilitas dalam hukum, sedangkan yang "seharusnya" menggambarkan tujuan tertinggi hukum, yaitu keadilan mutlak. Oleh sebab itu, hukum Islam meliputi hukum yang menjadi kenyataan maupun yang seharusnya, yaitu positivisme hukum dan hukum alam dalam pengertian ideal.

Sedangkan hukum positif, menurut Austin, adalah ilmu yurisprudensi tanpa memperhatikan kebaikan dan keburukan. Oleh sebab itu, hukum positif menurut Austin terlepas dari keadilan, sementara keadilan merupakan bagian inti dari hukum Islam.

Keadilan dalam hukum Islam berarti keseimbangan antara kewajiban yang harus dipenuhi dengan kemampuan untuk menunaikan kewajiban itu. Banyak ayat yang menunjukkan keseimbangan dan keadilan dalam perintah Tuhan. Oleh sebab itu, prinsip keadilan dalam prakteknya dapat berbuat sesuai dengan ruang dan waktu. Bila terjadi perubahan, kesulitan menjadi kelonggaran, maka terbataslah kelonggaran itu sekedar terpenuhinya kebutuhan yang bersifat primer atau sekuder. ${ }^{24}$

Dalam teori hukum, positivisme dan idealisme digambarkan saling bertentangan. Teori-teori idealistis di samping didasarkan pada prinsip-prinsip keadilan, juga berkaitan dengan hukum yang seharusnya, sementara teori positivistik diilhami oleh pandangan-pandangan tentang hukum yang bertentangan. Positivisme analitik memfokuskan diri pada analisa-analisa hukum, dan hubunganhubungan hukum berdasarkan pada pembagian ketat, apa yang nyata dan apa yang seharusnya, yang karenanya ia dipisahkan dari keadilan. Positivisme pragmatis memandang fakta sosial sebagai unsur yang menentukan konsep hukum. Bagi positivisme analitik, hukum berarti perintah dari penguasa, yang menyebabkan ia stabil. Sedangkan positivisme pragmatik menganggap bahwa hukum tuntuk kepada masyarakat, yang menyebabkan ia selalu berubah sesuai dengan setiap perubahan yang terjadi dalam masyarakat. Dengan demikian, dapat dipahami bahwa positivisme hukum merupakan korban ketegangan dan konflik.

${ }^{24}$ Juhaya S. Praja, Filsafat Hukum Islam, Kerjasama PT. Lathifah Press dengan Fakultas Syariah IAILM-Suryalaya, Tasiklamaya, 2009, hlm. 74. 
Selain itu, positivisme analitik dipisahkan dari keadilan dan etika, sementara hukum alam hadir sebagai hukum yang ideal dan lebih tinggi untuk digunakan sebagai standar keadilan. Akan tetapi karena hukum alam didasarkan kepada akal yang selalu berubah, maka ia tidak dapat bertopang pada dirinya sendiri, yang akhirnya mengalami kegagalan. Oleh karena ada pemisahan antara apa yang "nyata" dengan apa yang "seharusnya", maka tidak akan ada perdamaian atau titik temu antara hukum positif dan hukum alam. Sedangkan hukum Islam mengkombinasikan hukum sebagai "adanya" dan hukum sebagai yang "seharusnya”, sekaligus mempertahankan perintah dan keadilan. Sebagai perintah Tuhan dan Penguasa Tertinggi, maka hukum Islam adalah hukum positif. Oleh karena memberikan perhatian khusus kepada keadilan, maka hukum Islam bersifat ideal. Jadi, dapat digambarkan secara tepat sebagai hukum positif dalam bentuk ideal.

Dalam hukum Islam, positivisme dan idealisme dalam pengertian yang sesungguhnya, tidak hanya sekedar dapat dikombinasikan, tetapi benar-benar harmonis satu sama lain.

Hukum Islam diturunkan dalam bentuk yang umum dan garis besar permasalahan. Hukum-hukumnya bersifat tetap, tidak berubah lantaran berubahnya masa dan berlainnya tempat. ${ }^{25}$ Untuk hukum-hukum yang lebih rinci, hukum Islam hanya menetapkan kaedah dan memberikan pedoman umum. ${ }^{26}$ Penjelasan dan rinciannya diserahkan pada hasil ijtihad. ${ }^{27}$

Dengan menetapkan pedoman umum, hukum Islam benar-benar dapat menjadi petunjuk yang universal, dapat diterima di semua tempat dan setiap saat. Setiap waktu umat manusia dapat menyesuaikan tingkah lakunya dengan garis besar hukum Islam, sehingga mereka tidak melenceng. ${ }^{28}$

Penetapan Tuhan tentang hukum dalam bentuk yang global dan simpel itu, dimaksudkan agar dapat memberikan kebebasan pada umat manusia untuk melakukan ijtihad sesuai dengan situasi dan kondisi zaman. ${ }^{29}$ Dengan sifatnya yang global ini, maka hukum Islam dapat berlaku sepanjang masa.

\footnotetext{
${ }^{25}$ Fathurrahman Djamil, Filsafat Hukum Islam, Cetakan ke-3, Logos Wacana Ilmu, Jakarta, 1999, hlm. 46.

${ }^{26}$ Anwar Harjono, Hukum Islam, Keluasan dan Keadilannya, Bulan Bintang, Jakarta, 1975, hlm. 113.

${ }^{27}$ Hasbi Ash-Shiddieqiy, Dinamika dan Elastisitas Hukum Islam, Tinta Mas, Jakarta, 1975, hlm. 23-24.

${ }^{28}$ Fathurrahman Djamil, Op cit, hlm. 47.

${ }^{29}$ Joseph Schacht, An Introduction of Islamic Law, Alihbahasa M. Syarifuddin, (Ed), Departemen Agama RI, Jakarta, 1985, hlm. 264.
} 


\section{Penutup}

Aliran hukum alam telah ada sejak zaman Yunani Kuno, yang terfokus untuk mencari keadilan mutlak. Aliran ini tampil sebagai ekspresi pencarian sebuah ideal yang tertinggi. Dengan perubahan kondisi sosial dan politik, hukum alam mengalami perubahan.

Hukum alam banyak dikritik oleh para filsuf, sehingga mengalami kemunduran, dan digantikan, antara lain oleh aliran hukum positif. Pada abad ke- 20, hukum alam bangkit dengan pemikiran baru, terutama aliran neothomisme. Aliran hukum positif muncul di pertengahan abad ke-19, sebagai aliran yang menentang tendensitendensi metafisik yang ada sebelumnya. Aliran ini muncul sebagai sebuah sikap ilmiah, menolak spekulasi-spekulasi apriori, dan berusaha membatasi diri pada data pengalaman.

Aliran hukum positif dan hukum alam diigambarkan saling bertentangan. Teoriteori idealistis hukum alam di samping didasarkan pada prinsip keadilan, juga berkaitan dengan hukum yang seharusnya. Sedangkan aliran hukum positif diilhami oleh pandangan tentang hukum yang bertentangan. Positivisme analitik memfokuskan diri pada analisa dan hubungan hukum berdasarkan secara ketat, apa yang nyata dan apa yang seharusnya, sehingga terpisah dari keadilan. Positivisme pragmatis memandang fakta sosial sebagai unsur yang menentukan konsep hukum. Bagi positivisme analitik, hukum berarti perintah dari penguasa. Sedangkan positivisme pragmatik menganggap bahwa hukum tunduk kepada masyarakat. Aliran positivisme hukum merupakan korban ketegangan dan konflik.

Positivisme analitik dipisahkan dari keadilan dan etika, sedangkan hukum alam hadir sebagai hukum yang ideal dan lebih tinggi untuk digunakan sebagai standar keadilan. Oleh karena hukum alam didasarkan kepada akal, maka tidak dapat bertahan. Terdapat pemisahan antara apa yang "nyata" dengan apa yang "seharusnya", sehingga sulit terjadi titik temu antara hukum positif dan hukum alam. Hukum Islam mengkombinasikan hukum sebagai "adanya" dan yang "seharusnya", sekaligus mempertahankan perintah dan keadilan. Sebagai perintah Tuhan, maka hukum Islam adalah hukum positif. Oleh karena memberikan perhatian khusus kepada keadilan, maka hukum Islam bersifat ideal. Jadi, dapat digambarkan secara tepat sebagai hukum positif dalam bentuk ideal. Dalam hukum Islam, positivisme dan idealisme, tidak hanya sekedar dapat dikombinasikan, tetapi harmonis satu sama lain. 


\section{Daftar Pustaka}

\section{Al-Quran Al-Karim}

Ash-Shiddieqiy, Hasbi, Dinamika dan Elastisitas Hukum Islam, Tinta Mas, Jakarta, 1975.

Djamil, Fathurrahman, Filsafat Hukum Islam, Logos Wacana Ilmu, Jakarta, 1999.

Friedmann, W., Legal Theory, Fourth Edition, Stevens and Sons Limited, London, 1960.

, Teori dan Filsafat Hukum: Telaah Kritis Atas Teori-Teori Hukum, (Susunan I), PT. Raja Grafindo Persada, Jakarta, 1990.

Ghafur Anshari, Abdul, Filsafat Hukum Kewarisan Islam: Konsep Kewarisan Bilateral Hazairin, Cetakan ke-2, UII Press, Yogyakarta, 2010. Filsafat Hukum, Gajah Mada University Press, Yogyakarta, 2006.

Harjono, Anwar, Hukum Islam, Keluasan dan Keadilannya, Bulan Bintang, Jakarta, 1975.

Hart, H.L.A., The Consept of Law, Cetakan ke-2, Alih bahasa M. Khozim, Nusa Media, , Bandung, 2010.

Huijbers, Theo, Filsafat Hukum Dalam Lintasan Sejarah, Kanisius, Yogyakarta, 1982.

Kelsen, Hans, Pure Theory of law, Cetakan ke-6, Alih bahasa Raisul Muttaqin, Nusa Media, Bandung, 2008.

Muslehuddin, Muhammad, Philosophy of Islamic Law and the Orientalist: A Comparative Study of Islamic Legal System, Cetakan ke-2, Alih bahasa: Yudian Wahyudi Asmin, Tiara Wacana, 1997.

Rahardjo, Satjipto, Ilmu Hukum, Cetakan V, PT. Citra Aditya Bakti, , Bandung, 2000.

Rasyidi, B. Arief Sidharta, Lili, (Penyunting), Filsafat Hukum Mazhab dan Refleksinya, Cetakan Kedua, PT. Remaja Rosdakarya, Bandung, 1994.

S. Praja, Juhaya, Filsafat Hukum Islam, Kerjasama PT. Lathifah Press dengan Fakultas Syariah IAILM-Suryalaya, Tasiklamaya, 2009.

Schacht, Joseph, An Introduction of Islamic Law, Alih bahasa M. Syarifuddin, (Ed), Departemen Agama RI, Jakarta, 1985. 